\title{
USING CEMENT KILN DUST AS LOW PERMEABLE BARRIER FOR RESTRICTION THE PROPAGATION OF CADMIUM IONS TOWARDS THE WATER RESOURCES
}

M. M. Ibreesam

Researcher
A. A. H. Faisal

Prof.

Dept. of Environment.- Coll.of Eng.-University of Baghdad

\section{ABSTRACT}

eng_manal26@yahoo.com

ayadabedalhamzafaisal@yahoo.com

This study was aimed to determine the interaction of cement kiln dust - aqueous solution contaminated with Cadmium ions was studied through set of batch tests with operational conditions of contact time $\leq 120 \mathrm{~min}$, sorbent dosage from 0.05 to $1 \mathrm{~g} / 100 \mathrm{~mL}$ and agitation speed ranged from 50 to $300 \mathrm{rpm}$ for initial concentration of $50 \mathrm{mg} / \mathrm{L}$ with initial $\mathrm{pH}$ of 3 to simulate the acetogenic phase in the sanitary landfill. The best values of these conditions are 1 $\mathrm{hr}, 0.7 \mathrm{~g} / 100 \mathrm{~mL}$ and $250 \mathrm{rpm}$ respectively, To obtain maximum removal efficiencies of 97.6\%. Freundlich and Langmuir models have a high ability in the representation of the sorption data with determination coefficient $\left(R^{2}\right)$ greater than 0.97 and the sorption capacity reached to $84.1 \mathrm{mg} / \mathrm{g}$. This certifies that the physical sorption and chemisorption can occur together to remove Cadmium ions from the aqueous solutions. Tests elucidated that the average coefficient of the hydraulic conductivity is equal to $9.7 \times 10^{-13} \mathrm{~m} / \mathrm{s}$ and this is suitable for LPB. Finally, COMSOL Multiphysics 3.5a package was able to simulate the distribution of cadmium ions concentrations within two-dimensional physical model packed with sand aquifer and CKD LPB. A good matching between model predictions and experimental results are recognized at selected points up and down gradient of LPB.

Keywords: barriers technology; groundwater contamination; COMSAL software; sorption.

ابريسم و فيصل مجلة العلوم الزراعية العراقية - $1592-1581: 51$ (6)

استعمال غبار الاسمنت كحاجز منخفض النفاذية لمنع وتقييا استعمال أيونات الكادميوم في اتجاه موارد المياه.

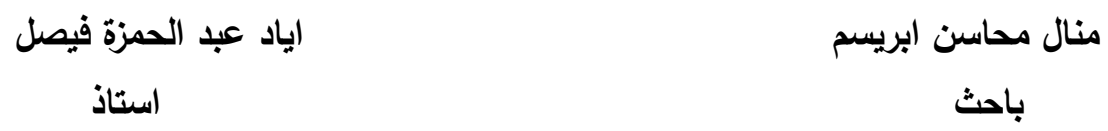

قسم الهندسة البيئية -كلية الهندسة- جامعة بغداد

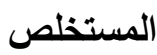

يرهف البحث الى دراسة تفاعل غبار الأسمنت مع المحلول المائي الملوث بأيونات الكادميوم من خلال مجموعة من اختبارات الأفعات مع الظروف التشغيلية لوقت التلامس > 120 دقيقة، والجرعة الماصة من 120.05 إلى 10. سرعة التحريك من 50 إلى 300 دورة في الدقيقة في البداية مع تركيز 50 ملغ / لتر للكادميوم مع الرقم الهيدروجيني الأولي

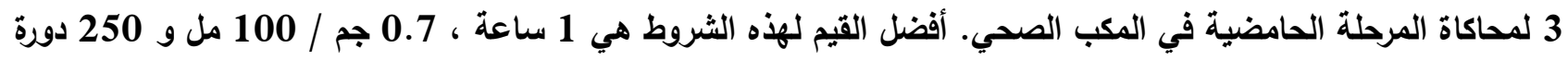
في الدقيقة على الترتيب للحصول على أقصى كفاعة إزالة 97.6 ٪. تتمتع الموديلات Freundlich و عالية في تمثيل بيانات الامتصاص ذات معامل التحديد (R2) أكبر من 0.97 وقدرة الامتصاص تصل إلى 84.1 ملفم / جم. هذا يشهر أن الامتصاص الفيزيائي والكيميائي يمكن أن يحدثا معًا لإزالة أيونات الكادميوم من الماتئ المحاليل المائية. أوضحت

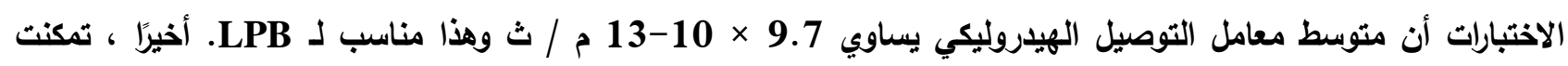

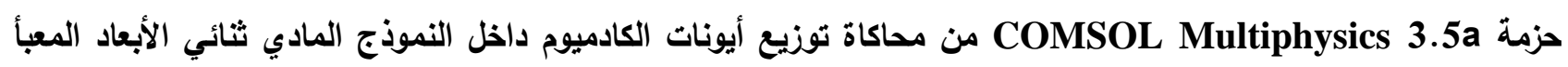
بخزانات المياه الجوفية الرملية و CKD LPB. يتم التعرف على تطابق جيذ بين تتبؤات النماذج والنتائج التجريبية في نقاط

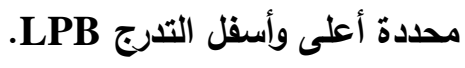

الكلمات المفتاحية: تقتية الحواجز , ملوثات المياه الجوفية ,الموديل COMSOL,الامتزاز

*Received:12/12/2019, Accepted:18/2/2020 


\section{INTRODUCTION}

Water present beneath the ground surface is known as "groundwater" which can be infiltrated from the surface by migration through the soil matrix of geologic formations. It becomes necessary to exploit the groundwater. Arab World has a groundwater reserve around 14.3 thousand billion cubic meters (11). Groundwater is a vital source because previous records signified that the 2 billion people depends mainly on this water for domestic uses and the $40 \%$ of food production through the worldwide is based on irrigation with groundwater; accordingly, this water considers a vital resource $(18,21)$. Previous studies signified that the contamination of aquifer will prohibit the use of its water for long periods of time reached to several decades (17). Heavy metals like Cadmium have a good ability for accumulation in the web of aquatic food to reach the human beings and cause many pathologies (2). In Japan, the spreading of Itai-itai disease in the 1950s was attributed to the presence of Cadmium element (resulted from base-metal mining) with high concentrations in water applied in the irrigation of rice fields. The heavy metals in groundwater may be resulted from water infiltration through the polluted layers of the soil (9). Also, solid wastes like municipal solid waste incineration ash, waste rock and others may be represented a familiar sources of the heavy metals through the leaching process. The groundwater must be protected by applying the familiar technologies like permeable reactive barriers (PRBs), low permeable barriers (LPBs). The LBPs technology can be used to contain contaminants in an aquifer and prevent the further spreading of contaminants in groundwater. Applying this technique in the restriction of groundwater contaminated with heavy metals has been proved to be successful and most efficient in the redirection or capturing of contamination plume The heavy metals can be captured by the reactive material used within the low permeable barrier technology by the following mechanisms; chemical precipitation, sorption, ion exchange, abiotic reduction and biotic reduction. In fact, with many cases, remediation of contaminated groundwater can be achieved by one or more of these processes. To keep LPB costs to the minimum, the material should be persisting with the time and readily available at low cost. Cement kiln dust (CKD) is alkaline powder solid waste resulted from the cement industry as byproduct; however, about $41 \mathrm{~kg}$ of this waste can be accompanied with production of 1-ton of cement (23); so, huge amounts of this waste will form a burden on the environment (4). The popular material used in the restriction the contaminant transport in the subsurface environment is the clay (or bentonite) as in the liner of the sanitary landfill to prevent the movement of leachate or in the hydraulic barrier for redirection the flow faraway of water resource. So, the reuse of $\mathrm{CKD}$ as an alternative choice to the bentonite due to its mentioned information is very important in the fields of sustainable development and green projects as well as the reducing of disposal charges (15). The CKD is classified chemically as a high heterogeneous material and, therefore, this material can remove the dissolved metal in the aqueous solution by adsorption and precipitation (22). The relationships between water content, compaction, hydraulic conductivity, and dry unit weight have identified in the rigid- and flexible- wall permeameters. The results proved that the suitability of the sand in the formation of low hydraulic conductivity barrier layers to be used as pits and covers in landfills, ponds, and sewage lakes (3). The 2D steady groundwater flow beyond the LPB embedded in the flow domain was solved analytically for finding the discharge vector and hydraulic head. Also, the developed solution applied to investigate the role of extraction wells and vertical barrier in the containment of pollution front (6). The ability of synthetic clay linings (GCL) to prevent contaminants from moving into groundwater as they are used in the design of the landfill barrier was studied (8). The study was implemented to investigate the applicability of seven clayey substrates taken from countryside regions in Poland as durable, successful and sustainable materials for constructing the liners of the waste landfill for preventing the leachate seepage to surrounding environment (16). This study was aimed to consider a good application for the principles of sustainability 
because it investigates the possibility of using cement kiln dust solid waste as LPB as alternative to natural clay for preventing a further spreading of Cadmium ions in the groundwater. The performance of this material was evaluated by sets of batch and continuous tests as well as COMSOL Multiphysics 3.5a (2008) used to simulate the spreading of the Cadmium ions.

\section{MATERIALS AND METHODS}

Materials: The CKD was collected from the Al-Kufa cement factory, Kufa, Al-Najaf city, Iraq with physical appearance shows in Fig. 1. It considers heterogeneous material with composition consisted of $\mathrm{CaO}, \mathrm{SiO}_{2}, \mathrm{Al}_{2} \mathrm{O}_{3}$, $\mathrm{Fe}_{2} \mathrm{O}_{3}, \mathrm{MgO}, \quad \mathrm{SO}_{3}, \quad \mathrm{Na}_{2} \mathrm{O}$ and $\mathrm{K}_{2} \mathrm{O}$ with percentages of $43.99,15.05,4.43,2.23,1.64$,
6.02, 0.69 and 4 (14) (25). The specific surface area of CKD was found equal to $5200 \mathrm{~cm}^{2} / \mathrm{g}$ measured according to ASTM C 204-05 using the Blaine-air permeability apparatus available in the Physical Laboratory of Kufa Cement Plant, Southern Cement Company (20). Sand was used, sieved for size ranged from $0.6 \mathrm{~mm}$ to $1 \mathrm{~mm}$. This quartz sand was obtained from the granular filter factory in Najaf, Iraq. The sand was washed thoroughly with distilled water before use and then dried using the oven for 2 hours under $230^{\circ} \mathrm{C}$. Quartz sand is characterized by a uniform distribution of grain size with median size $\left(\mathrm{d}_{50}\right)$ of 0.7674 $\mathrm{mm}$. The bulk density, porosity and hydraulic conductivity coefficient have value of 1.7335 $\mathrm{g} / \mathrm{cm}^{3}, 0.31$, and $4.1 \times 10^{-4} \mathrm{~m} / \mathrm{s}$ respectively.

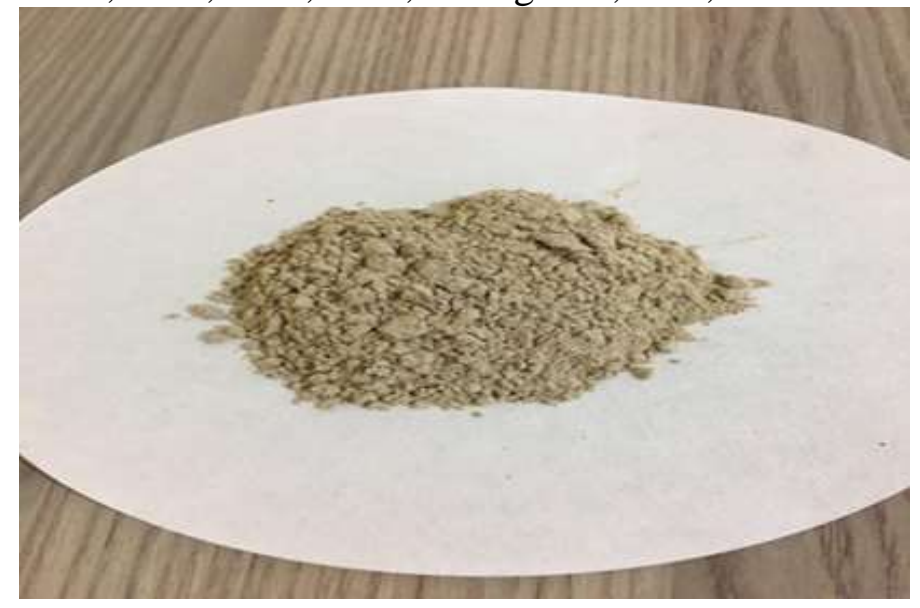

Figure 1. Physical appearance of cement kiln dust used in this study

Contaminant: To prepare the water sample with Cadmium concentration of $1000 \mathrm{mg} / \mathrm{L}$, $2.744 \mathrm{~g}$ of $\mathrm{Cd}\left(\mathrm{NO}_{3}\right)_{2} .4 \mathrm{H}_{2} \mathrm{O}$ was dissolved in one liter of distilled water and this solution was kept at room temperature. The solution was used as stock solution to prepare any specific concentration of Cadmium by dilution and its $\mathrm{pH}$ adjusted to became 3 to represent the acetogenic phase of leachate by adding 0.1 $\mathrm{M} \mathrm{HNO}_{3}$ or $\mathrm{NaOH}$ as required.

Batch experiments: They were carried out to determine the best conditions that required to achieve the maximum removal efficiency of pollutant. These conditions included contact time, adsorbent dosage, initial metal concentration and agitation speed for certain value of initial concentration and initial $\mathrm{pH}$ of the solution. Series of $250 \mathrm{~mL}$ flasks were employed and each flask was filled with 100 $\mathrm{mL}$ of cadmium solution which has initial concentration $\left(C_{o}\right)$ of $50 \mathrm{mg} / \mathrm{L}$. The CKD dosages $(m)$ of $(0.05,0.1,0.3,0.5,0.7,0.9$ and
$1 \mathrm{~g}$ ) were added to the different flasks and they have been stirred in the high-speed orbital shaker (Edmund Buhler SM25, German) at $250 \mathrm{rpm}$ for 1 hour. A fixed volume $(20 \mathrm{~mL})$ of the solution was withdrawn from each flask and filtered using filter paper type (JIAO JIE 102) to separate the adsorbent; then, fixed volume $(V=10 \mathrm{~mL})$ of the clear solution was utilized for the determination of the amount of unsorted metal ion still present in solution $\left(C_{e}\right)$. The measurements were carried out to concentration of cadmium using atomic absorption spectrophotometer (AAS, Sens AA, Australian). Different values of contact time $(0,50,100,150,200$ and 250) and agitation speed $(50,100,150,200$ and $250 \mathrm{rpm})$ for initial $\mathrm{pH}$ of 3 and initial concentration of 50 $\mathrm{mg} / \mathrm{L}$. The quantity of adsorbed contaminant $\left(q_{e}\right)$ was established by the mass balance using the following equation (10):

$q_{e}=\left(C_{o}-C_{e}\right) \frac{V}{m}$ 
The removal efficiency $(R)$ for all contaminants was determined by:

$$
R=\frac{\left(C_{o}-C_{e}\right)}{C_{\mathrm{o}}} \times 100
$$

\section{Pure precipitation}

In the present study, a set of batch experiments for finding the precipitation portion that occurs due to interaction of CKD and Cadmium ions have been conducted. The results of these experiments with outputs of experiments conducted to describe the total sorption can be used together to find the contribution of pure adsorption and pure precipitation in the total sorption of removal process. Batch equilibrium experiments for finding the removal of cadmium ions by pure precipitation were carried out by adding certain mass of CKD sorbent into $100 \mathrm{~mL}$ of acidic uncontaminated water $(\mathrm{pH}=3)$ and the solution was kept stirred at high-speed using orbital shaker for 1 $\mathrm{hr}$ at $250 \mathrm{rpm}$. The solution was then filtered to separate the sorbent using a procedure similar to the "tea bag" experiment (7). The clear solution was mixed with aqueous solution contaminated with cadmium ions and the resulting solution was filtered after the required equilibrium time. The concentration of the metal ions still present in the filter solution was measured by AAS and the precipitated concentration was obtained by the mass balance.
The 2D tank (Fig. 2) was performed to represent the migration of contaminant in the presence of CKD LPB embedded within the packed sandy aquifer. This glass tank has dimensions of $100 \mathrm{~cm} \times 40 \mathrm{~cm} \times 10 \mathrm{~cm}(\mathrm{~L} \times$ $\mathrm{W} \times \mathrm{H}$ ) and it is divided into three compartments by inserted two vertical perforated glass plates. These plates was covered with filter papers, provided the lateral boundaries for middle compartment (with dimensions $80 \times 40 \times 10 \mathrm{~cm})$ which is the location of the packed bed consisted of sand aquifer and CKD barrier. Storage tank with capacity of $80 \mathrm{~L}$, constant head reservoir, and flow meter are utilized to supply the required flowrate for packed bed. Samples have been taken periodically from the flowing water through the model aquifer by using stainless needles. Firstly, the $5 \mathrm{~cm}$ bed depth was packed in the middle compartment in the alignment measured from left side of the tank and composed of $50 \mathrm{~cm}$ sandy soil, $10 \mathrm{~cm}$ CKD LPB, and then $20 \mathrm{~cm}$ of the sandy soil. Monitoring of Cadmium concentrations in the selected sampling ports as shown in Fig. 2 for duration not exceeded 14 days was achieved. The $2 \mathrm{~mL}$ water samples were taken regularly (after 2,4, 8... 336 hours) from the mentioned ports to measure the cadmium concentration by AAS.

\section{Continuous experiments}
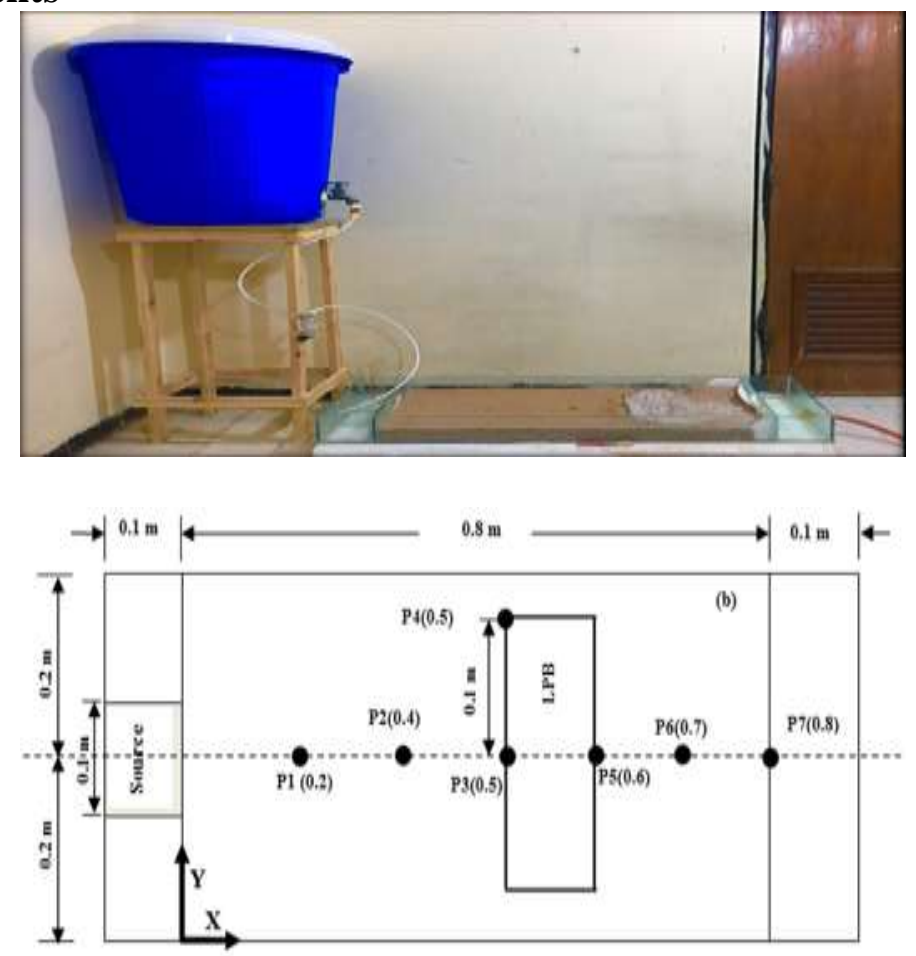

Figure 2. Set-up of two-dimensional experimental tank used in the present study 


\section{Modeling of batch and continuous outputs} Models of sorption

They related between the contaminant concentration sorbed on the solid phase of the sorbent $\left(q_{e}, \mathrm{mg} / \mathrm{g}\right)$ and concentration remaining in the liquid phase $\left(C_{e}, \mathrm{mg} / \mathrm{L}\right)$. The sorption models have many mathematical relationships like Langmuir and Freundlich as below:

$$
q_{e}=\frac{q_{\max } b C_{e}}{1+b C_{e}}
$$

where $b$ and $q_{\max }$ are the affinity constant $(\mathrm{L} / \mathrm{mg})$ and the maximum adsorption capacity $(\mathrm{mg} / \mathrm{g})$ respectively.

Freundlich model can be written as follows:

$$
q_{e}=K_{F} C_{e}^{1 / n}
$$

where $K_{F}$ is the Freundlich constant and $1 / n$ is the intensity of sorption (12).

\section{Modeling of Cadmium transport}

The model developed in this study to simulate the transport of cadmium ions in the 2D bed is based on the combination of two main equations; the first one for the flow of groundwater (Eq.5) and the second equation describes the transport of contaminant (named advection-dispersion equation, Eq.6) as follows:

$$
\begin{aligned}
& \frac{\partial}{\partial x}\left(K_{x} \frac{\partial h}{\partial x}\right)+\frac{\partial}{\partial y}\left(K_{y} \frac{\partial h}{\partial y}\right)=0 \\
& D_{x} \frac{\partial^{2} C}{\partial x^{2}}+D_{y} \frac{\partial^{2} C}{\partial y^{2}}-V_{x} \frac{\partial C}{\partial x}=\frac{\partial C}{\partial t}+\frac{\rho_{b}}{n} \frac{\partial q}{\partial t}
\end{aligned}
$$

where $K$ is the hydraulic conductivity coefficient $(\mathrm{m} / \mathrm{s}), \quad D$ is the dispersion coefficient $\left(\mathrm{m}^{2} / \mathrm{s}\right), \mathrm{V}$ is the seepage velocity $(\mathrm{m} / \mathrm{s}), h$ is the hydraulic head $(\mathrm{m}), \rho_{\mathrm{b}}$ is the bulk density $\left(\mathrm{kg} / \mathrm{m}^{3}\right)$. The Langmuir model must be incorporated with the last equation to describe the adsorption process in the transport of the contaminant and the resultant equation can take the following form:

$D_{x} \frac{\partial^{2} C}{\partial x^{2}}+D_{y} \frac{\partial^{2} C}{\partial y^{2}}-V_{x} \frac{\partial C}{\partial x}=R \frac{\partial C}{\partial t}$

and $R$ will be;

$$
\boldsymbol{R}=\mathbf{1}+\frac{\rho_{d}}{n}\left(\frac{q_{m} b}{(1+b C)^{2}}\right)
$$

where $R$ is the retardation factor.

\section{RESULTS AND DISCUSSION}

\section{$\mathrm{X}$-ray diffraction analysis}

The chemical composition of CKD sorbent was characterized using the $\mathrm{X}$-ray diffraction in Germany Laboratory_ Geology Department_College of Science_University of Baghdad. Fig.3 shows the XRD for CKD and it is clear that the Calcium and Silica oxides are the major constituents of its structure. All calcium in the CKD is assumed to be in the form of calcium oxide $(\mathrm{CaO})$; however, this not the real case. Some of the calcium may be in the form of Calcium carbonate $\left(\mathrm{CaCO}_{3}\right)$ (i.e. unreacted limestone), or Calcium sulphate $\left(\mathrm{CaSO}_{4}\right)$. The presence of lime is measure of the $\mathrm{CaO}$ content that readily available for reactions. Also, there is high content of free $\mathrm{CaO}$ (free lime), Calcium hydroxide, sulfates, and total alkalis. So, the CKD tends to have higher alkalinity behavior due to the mentioned constituents which play a potential role in the precipitation of the heavy metal. The presence of particles other than Calcium oxide can affect the solubility of $\mathrm{CaO}$ into $\mathrm{Ca}(\mathrm{OH})_{2}$. Specifically, interfering oxides such as magnesium oxide, silic, aluminum oxide, and unreacted $\mathrm{CaCO}_{3}$ particles may slow the rate of $\mathrm{Ca}(\mathrm{OH})_{2}$ dissolution. Oxides of potassium and magnesium can react with water to form the hydroxides of these elements which able to neutralize of acids in environmental systems.

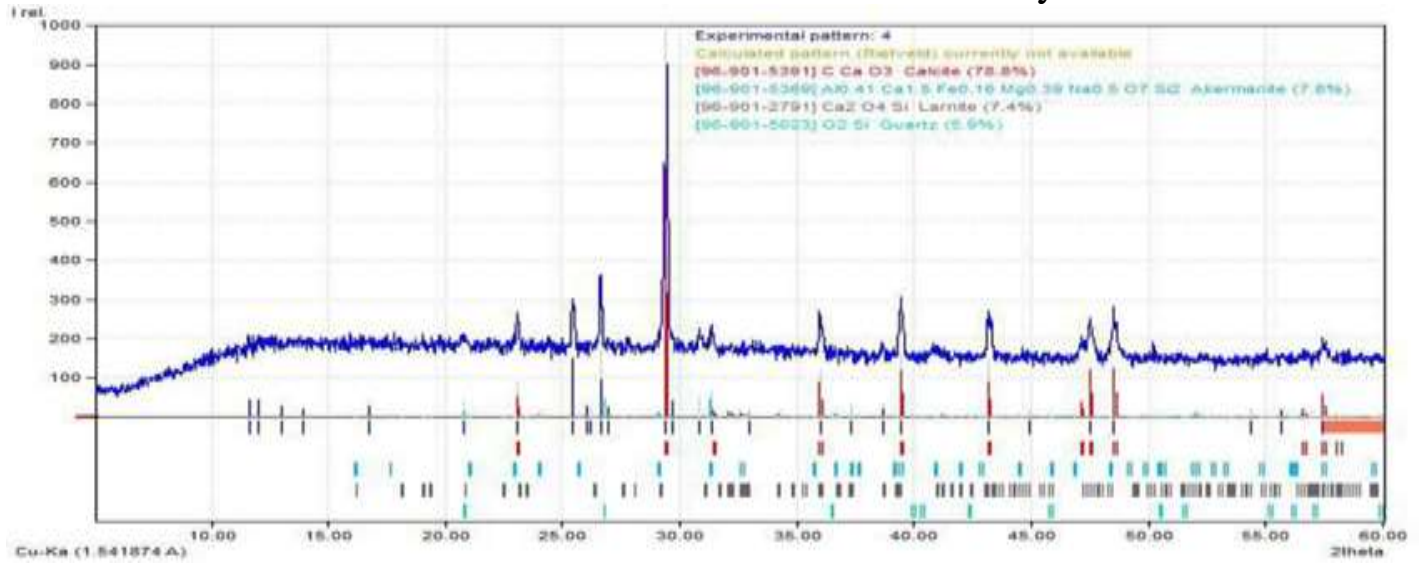

Figure 3. The X-ray diffraction (XRD) analysis for CKD 


\section{Coefficient of hydraulic conductivity}

The "falling head permeameter" utilized in the measurement of the hydraulic conductivity coefficient for bentonite material. The experiment was beginning by saturating the porous medium sample with tap water for duration not less than 2 days. The test is based on the monitoring of the falling head as a function of the time and the corresponding coefficient of hydraulic conductivity can be calculated. Results proved that the coefficient of hydraulic conductivity have the values of was decreased with the time from $2.05 \times 10^{-12}$, $1.30 \times 10^{-12}, \quad 9.20 \times 10^{-13}, \quad 5.82 \times 10^{-13}$ and $3.22 \times 10^{-13} \mathrm{~cm} / \mathrm{s}$ after $1,3,5,7$ and 9 days respectively with average value of $3.22 \times 10^{-13}$ $\mathrm{cm} / \mathrm{s}$. Due to the high density of the present reactive materials, this will cause the slowed flow within the internal pores and, consequently, the coefficient of hydraulic conductivity (K) will be low (24).

\section{Batch experiments}

Sorbent dosage: The relationships between the metal ions removal efficiencies and sorbent dosages of CKD are plotted in Fig. 4(a) for condition specified within this graph. It can be seen that the increase of sorbent mass will improve the removal efficiency and this may be attributed to available greater vacant sites. Also, this figure certifies that the sorption efficiency was increased from 48 to $90 \%$ due to increase of dosage from 0.05 to $0.3 \mathrm{~g} / 100$ $\mathrm{mL}$. Beyond the $0.3 \mathrm{~g} / 100 \mathrm{~mL}$, slow increase in the efficiency can be recognized; so, the dosage was chosen of $0.7 \mathrm{~g} / 100 \mathrm{~mL}$ to obtain of the fair value of removal efficiencies for Cadmium ions that reached to $97.6 \%$.
Contact time: Fig. 4(b) plots the variations of sorption efficiencies for Cadmium ions onto CKD versus the contact time under the relevant conditions specified within this graph. This figure reveals that the sorption rate is very fast within the first five minutes and at which the efficiency approaches to $94.05 \%$. Thereafter, the rate was gradually slowed and efficiency approximately stabilized beyond 1 $\mathrm{hr}$ at $97.6 \%$. The presence of sufficient numbers of the binding sites on the adopted sorbent may be the main reason for high rate of sorption process and its decrease with elapsed time can be resulted from the occupation of these sites by cadmium ions; however, the next tests can be implemented with contact time of $1 \mathrm{hr}$.

Agitation speed: This speed was changed within the range extended from 50 to $300 \mathrm{rpm}$ and the measured corresponding removal percentages of the cadmium ions have been plotted in the Fig. 4(c) under the operational conditions of $C_{o}=50 \mathrm{mg} / \mathrm{L}$, contact time $=1 \mathrm{hr}$, initial $\mathrm{pH}=3$, and dosage $=0.7 \mathrm{~g} / 100 \mathrm{~mL}$. For $\mathrm{CKD}$, the slight increase in the sorption efficiency from 91.8 to $100 \%$ can be observed due to change of agitation speed from 50 to $300 \mathrm{rpm}$. This means that the reactivity of CKD is very high due to generate two mechanisms namely adsorption and precipitation responsible of the removal process; so, the agitation speeds within the adopted range not have significant effect on the removal process. For practical purposes, the choice speed of $250 \mathrm{rpm}$ as best value for batch tests is satisfactory for two sorbents under consideration. 

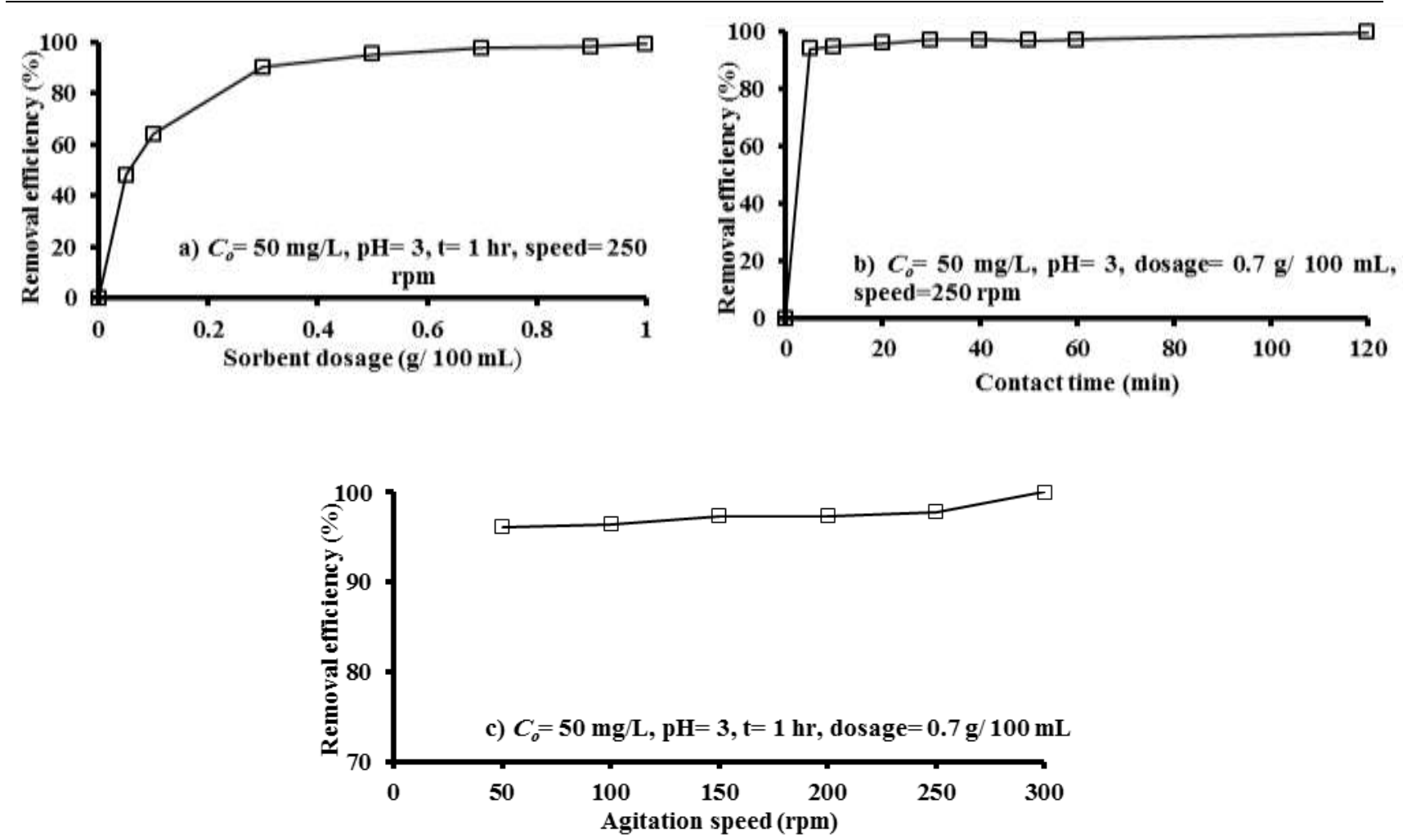

Figure 4. Trend of the relationships related between the removal efficiencies of the cadmium ions a) sorbent dosage, b) contact time and c) agitation speed

Pure precipitation in the Cadmium ionsCKD interaction

The removal of metal ions due to interaction with CKD sorbent is governed mainly by two mechanisms pure adsorption and pure precipitation. Based on the total sorption and pure precipitation measurements with applying the same procedure adopted by (1), the proportions of cadmium ions removed by pure adsorption and pure precipitation are plotted in Fig.5. In comparison with total sorption findings, it seems that there is a lag in the removal of cadmium by pure precipitation because the metal ions for this case not in direct contact with CKD. Also, this figure proved that the increase of sorbent dosage will associate with increase of metal ions removal due to the pure precipitation and, consequently, the decrease of ions removed by pure adsorption. This figure showed that the pure precipitation is governed the removal process in the high Cadmium concentrations due to the formation of Cadmium hydroxide as a result of the chemical reaction of CKD. In addition, the precipitation process may be faster than the adsorption process and this requires relatively longer time to achieve the maximum adsorption capacity. Accordingly, precipitation represents the predominant mechanism at high concentrations of the removal process, while adsorption will be the predominant mechanism at low metal concentrations. 


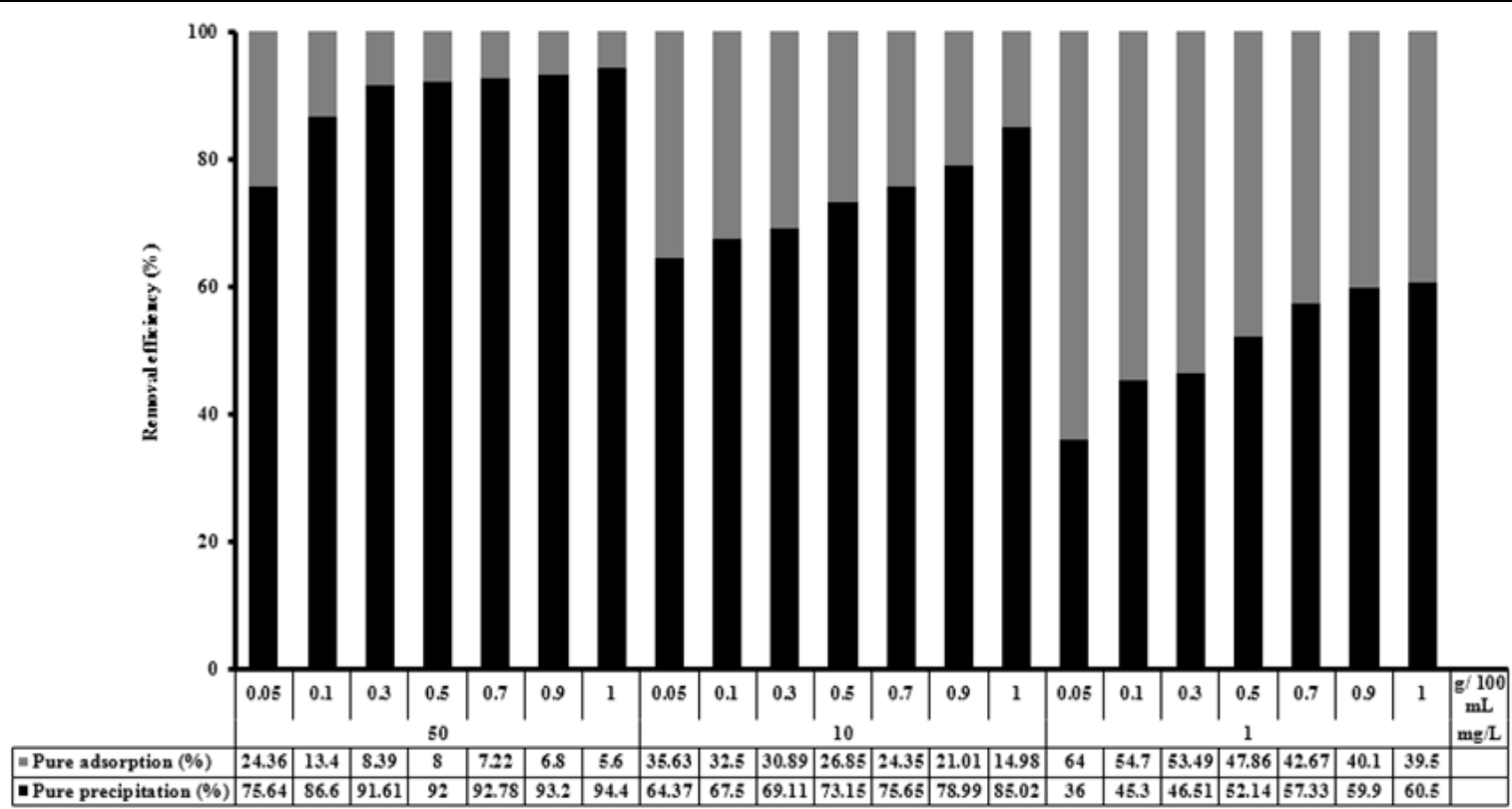

Figure 5. Pure adsorption and pure precipitation shares for removal of Cadmium ions onto CKD sorbent

Isotherm models for sorption data

Fig. 6 shows the isotherm models (Freundlich and Langmuir) that fit the sorption data to describe the removal of cadmium ions onto CKD reactive material. Constant of these models are listed in Table $\mathbf{1}$ and they are calculated by using non-linear regression

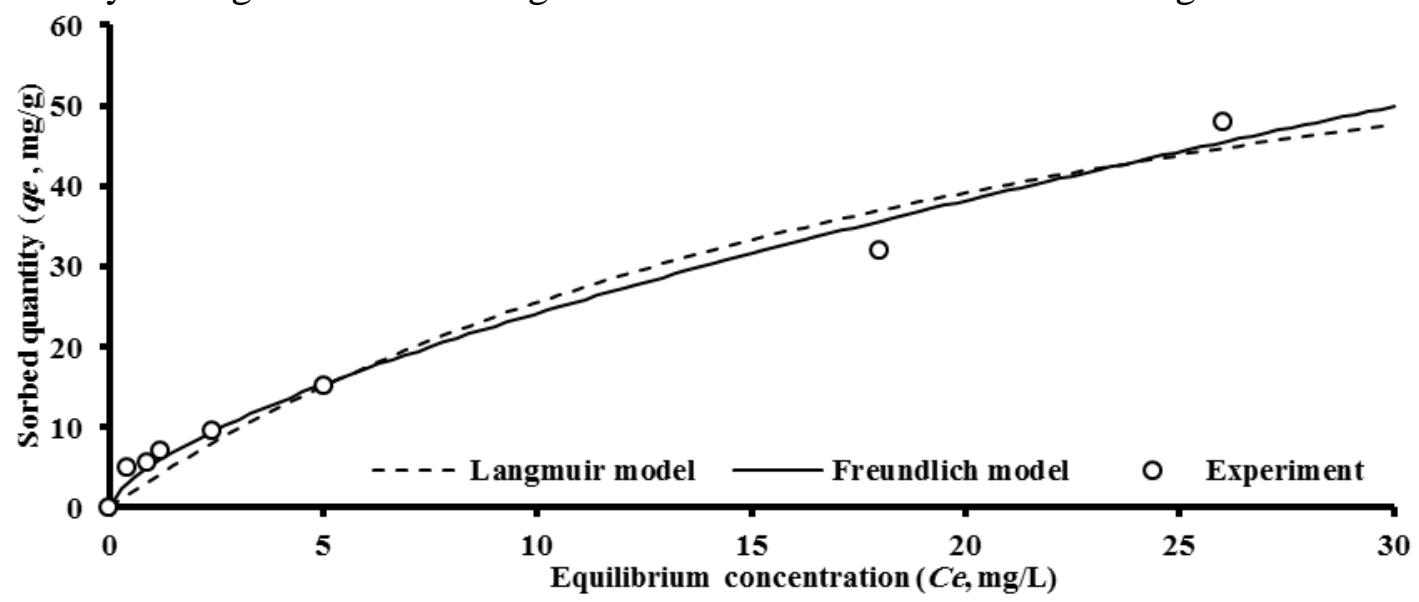

Figure 6. Isotherms models for sorption of cadmium ions onto CKD

Table 1. Constants of isotherm models for description the sorption of cadmium ions onto CKD

\begin{tabular}{|ccc|}
\hline Model & Parameter & Value \\
\hline & $K_{f}(\boldsymbol{m g} / g)(\mathrm{L} / \mathrm{mg})^{1 / n}$ & $\mathbf{5 . 2 7 6 0 8}$ \\
Freundlich & $n$ & 1.51359 \\
& $\mathbf{R}^{2}$ & $\mathbf{0 . 9 8 8 0 7}$ \\
& $\boldsymbol{q}_{\max }(\mathrm{mg} / \mathrm{g})$ & $\mathbf{8 4 . 1}$ \\
Langmuir & $\boldsymbol{b}(\mathrm{L} / \mathrm{mg})$ & $\mathbf{0 . 0 4 3 6 0}$ \\
& $\mathbf{R}^{2}$ & $\mathbf{0 . 9 7 4 7 1}$ \\
\hline
\end{tabular}

Fourier transform infrared (FTIR) sorbent material (13). The FTIR spectroscopy analysis: The pattern of Cadmium ions sorption onto the CKD is attributable to the active groups and bonds present on this fitting in Excel (2016) utilizing the "Solver" option. Results certified that the two models are able to represent of sorption data for case under consideration. The maximum adsorption capacity of CKD is equal to $84.1 \mathrm{mg} / \mathrm{g}$ as calculated from Langmuir model with affinity constant of $0.04360 \mathrm{~L} / \mathrm{mg}$. may be, therefore, done for specifying the preliminary functional groups present in the native CKD used as sorbent for cadmium ions. 
The characteristics bands of the CKD before and after Cadmium uptake at $\mathrm{pH} 3$ were used to assess the changes in the functional groups. Functional groups analysis using the FTIR was measured for samples obtained from the experiment before and after cadmium adsorption where results have been plotted in Fig.7. Within the range of wavelengths from 400 to $4000 \mathrm{~cm}^{-1}$, the $\mathrm{Si}-\mathrm{O}$ functional groups were observed at the $1107 \mathrm{~cm}^{-1}$. Bands at 3450

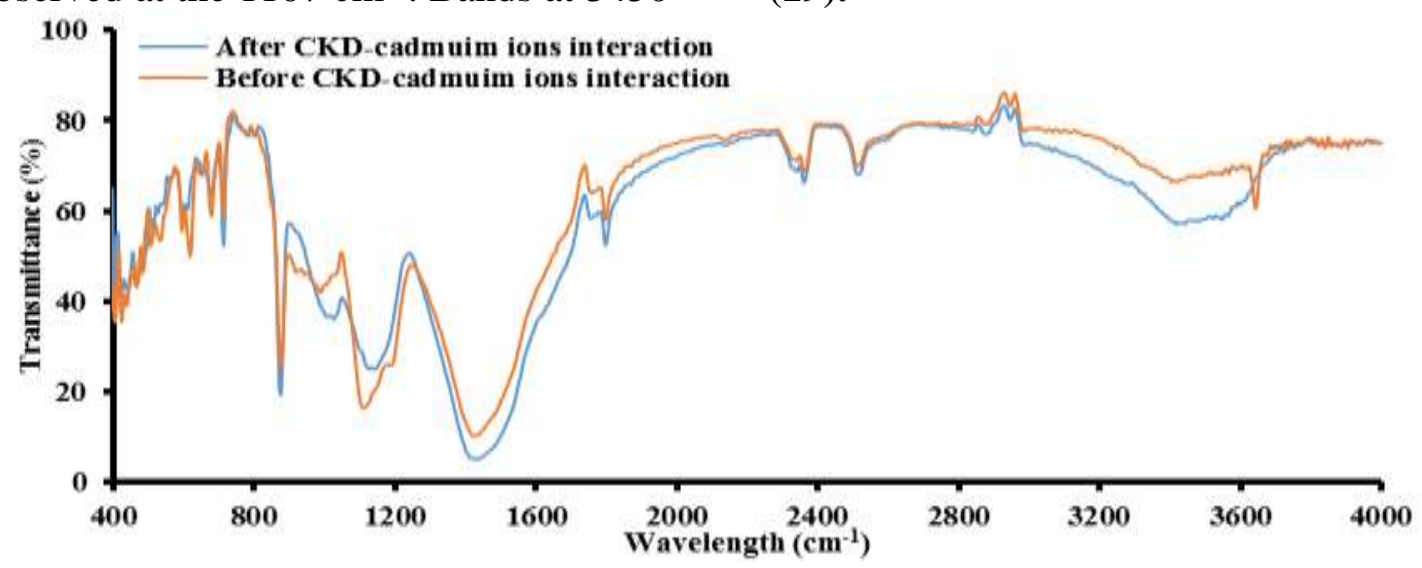

and $1450.0 \mathrm{~cm}^{-1}$ indicated the possibility of hydration by water or $\mathrm{H}-\mathrm{O}-\mathrm{H}$ bending of water in the adsorbent (5). FTIR spectra of cadmium ions showed that the peaks at 3450,1450, and $1140 \mathrm{~cm}^{-1}$ had been shifted due to interaction with Cadmium ions. These shifts may be attributed to the changes in counter ions associated with carboxylate and hydyroxylate anions which contributors in metal ion uptake (19).

Figure 7. FTIR analysis for CKD before and after sorption of cadmium ions

Contaminant transport in the $2 \mathrm{D}$ bed consisted of aquifer and LPB

Application of COMSOL Multiphysics was achieved to simulate the 2D steady flow of water and transient contaminant transport through the bed identical to the experimental setup mentioned previously. The model has dimensions of $0.8 \mathrm{~m}$ length, and $0.4 \mathrm{~m}$ width for bed height of $5 \mathrm{~cm}$; also, the alignment of LPB $(0.1 \times 0.3 \mathrm{~m})$ and line sourceof $0.10 \mathrm{~m}$.

Tables 2 and 3 listed all information required for modeling process. The ability of COMSOL Multiphysics 3.5a in the description of the Cadmium ions transport within the sand aquifer containing the CKD LPB was evaluated by comparison the predictions of the theoretical model with experimental measurements at selected within the LPB as depicted in Figure 8 for the locations (P1, P4, $\mathrm{P5})$. It is clear that there is a satisfactory agreement between the model outputs and experimental results; also, this figure certified that the proposed barrier play a significant in the protection of locations nearby it in the down-gradient and the contaminant concentration was increased with the time. Due to the presence of matching between model results and measurements, the present simulation based on the COMSOL package can be utilized to predict the spatially and temporally normalized concentrations of Cadmium ions within the physical bed. Accordingly, Fig.9 is introduced the predictions of breakthrough curves for locations (P2, P3, P6, P7) up- and downgradient of LPB. Figs. 8 and 9 elucidate that the concentrations of contaminant have the lowest values in the locations adjacent to the LPB from down gradient side. Also, the hydraulic head and velocity values were plotted in the flow field under the effect of LPB as shown in Fig. 10. The barrier has ability to create two stagnant points in the upand down- gradient sides of this wall with significant change in the advection front in the locations nearby the LPB. This figure elucidates that the velocity of the flow is decreased significantly inside the barrier, while a smaller region of reduced speed can be observed outside the LPB. Fig.11 plots the contours of Cadmium normalized concentration across the bed model as predicted by the COMSOL software for various times. The LPB situated beyond the line source of contamination is caused a significant reduction in the rate of advective transport with lateral deviation of the contaminant plume as the streamlines spread to pass the barrier. 
Table 2. Constants utilized for modeling of $2 \mathrm{D}$ transport of contaminant in the LPB and aquifer

\begin{tabular}{|ccc|}
\hline Bed & Variable & Value \\
\hline & $n$ & $\mathbf{0 . 3 1}$ \\
Sand aquifer & K & $4.1 \times 10^{-4}$ \\
& $\rho_{b}$ & 1733.5 \\
& $n$ & 0.62 \\
LPB & K & $9.7 \times 10^{-15}$ \\
& $\rho_{b}$ & 1170 \\
\hline
\end{tabular}

$n=$ Porosity; $\mathrm{K}=$ Hydraulic conductivity $(\mathrm{m} / \mathrm{s}) ; \rho_{b}=$ Bulk density $\left(\mathrm{kg} / \mathrm{m}^{3}\right)$

Table 3. Conditions adopted in the modeling of Cadmium ions transport for the 2D

laboratory scale tank

\begin{tabular}{|cccc|}
\hline Item & Location & Type & Value \\
\hline \multirow{3}{*}{ Boundary conditions for fluid flow } & Line source & Hydraulic head $(\mathbf{c m})$ & 5 \\
& Outlet side & Hydraulic head $(\mathbf{c m})$ & zero \\
& All other sides & Zero flux/symmetry & $-\cdots---$ \\
& Line source & Concentration $(\mathbf{m g} / \mathbf{L})$ & 50 \\
Boundary conditions for solute transport & Outlet side & Advective flux & $-\cdots---$ \\
& All other sides & No flux/symmetry & ---- \\
Initial condition for solute transport & ---- & Concentration $(\mathbf{x , y})$ at t=0 & zero \\
\hline
\end{tabular}

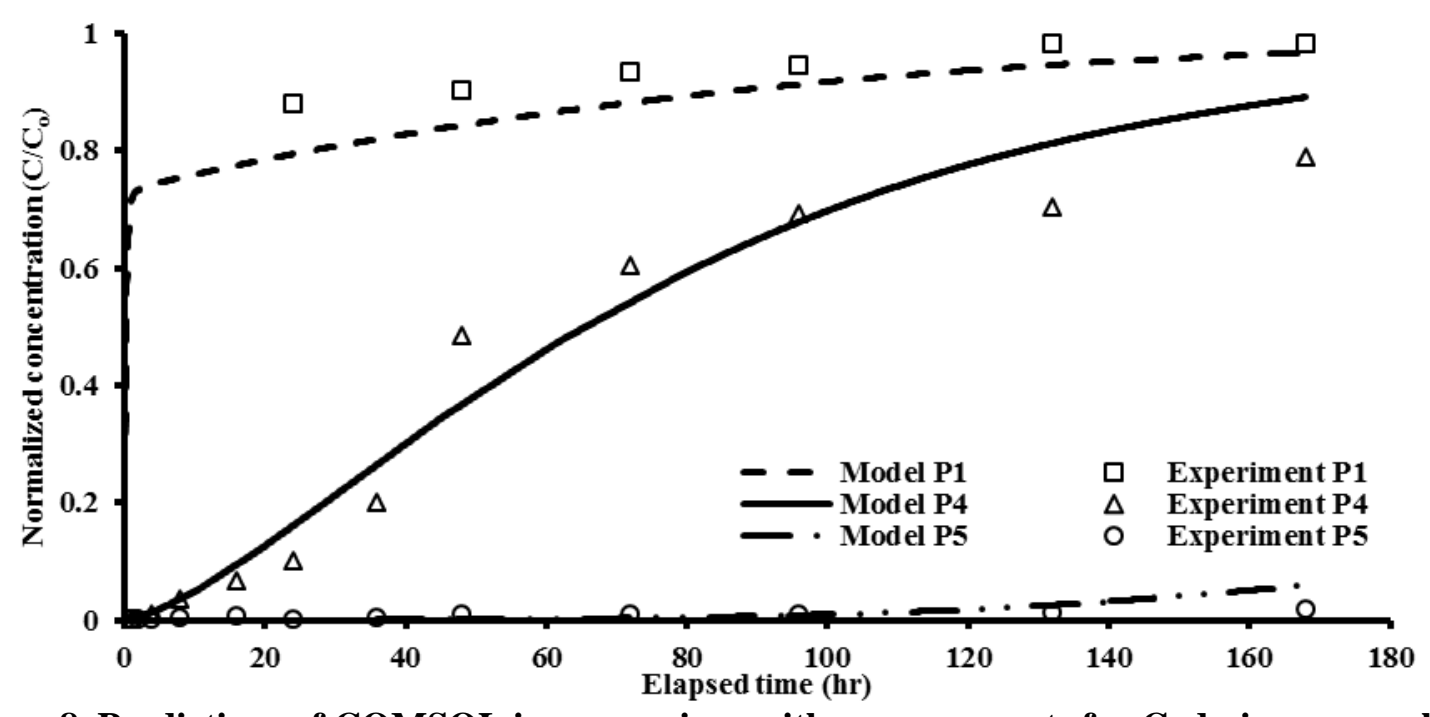

Figure 8. Predictions of COMSOL in comparison with measurements for Cadmium normalized concentrations in the selected points for sand aquifer with presence of CKD as LPB

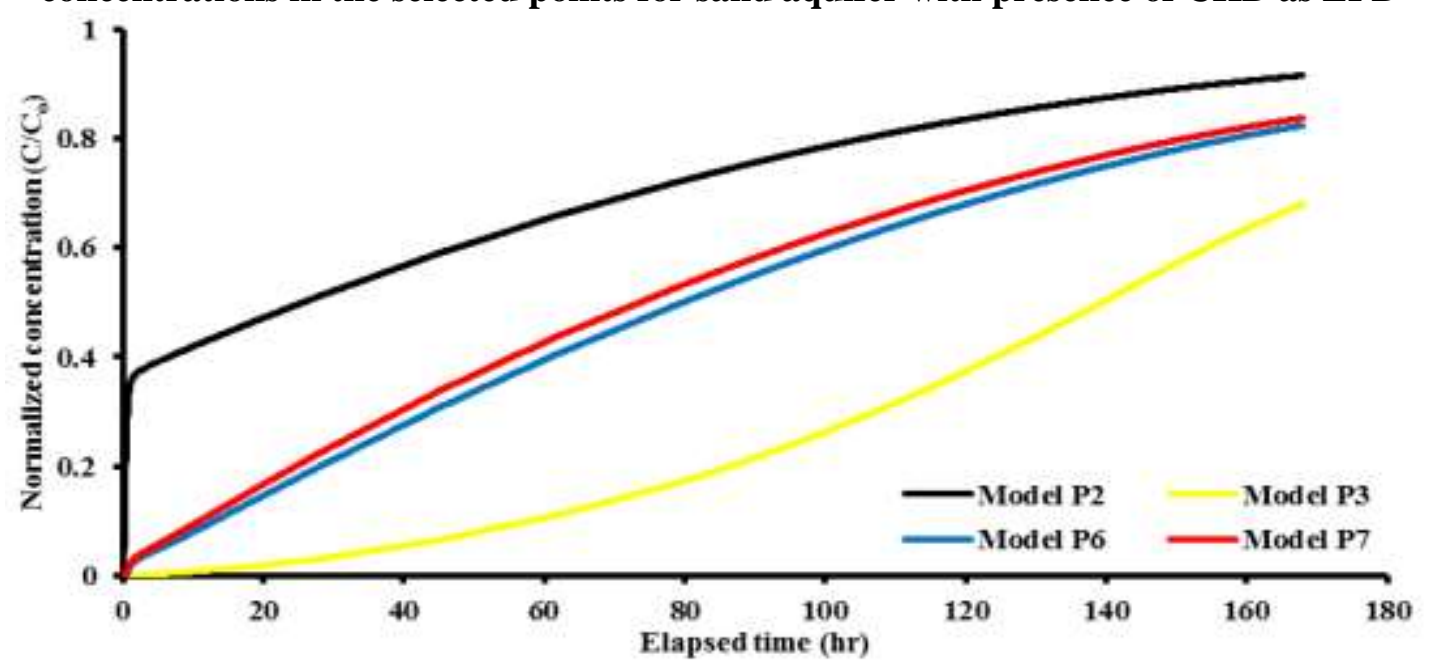

Figure 9. Predicted values of cadmium normalized concentrations using COMSOL package in the selected points for sand aquifer with presence of CKD as LPB 


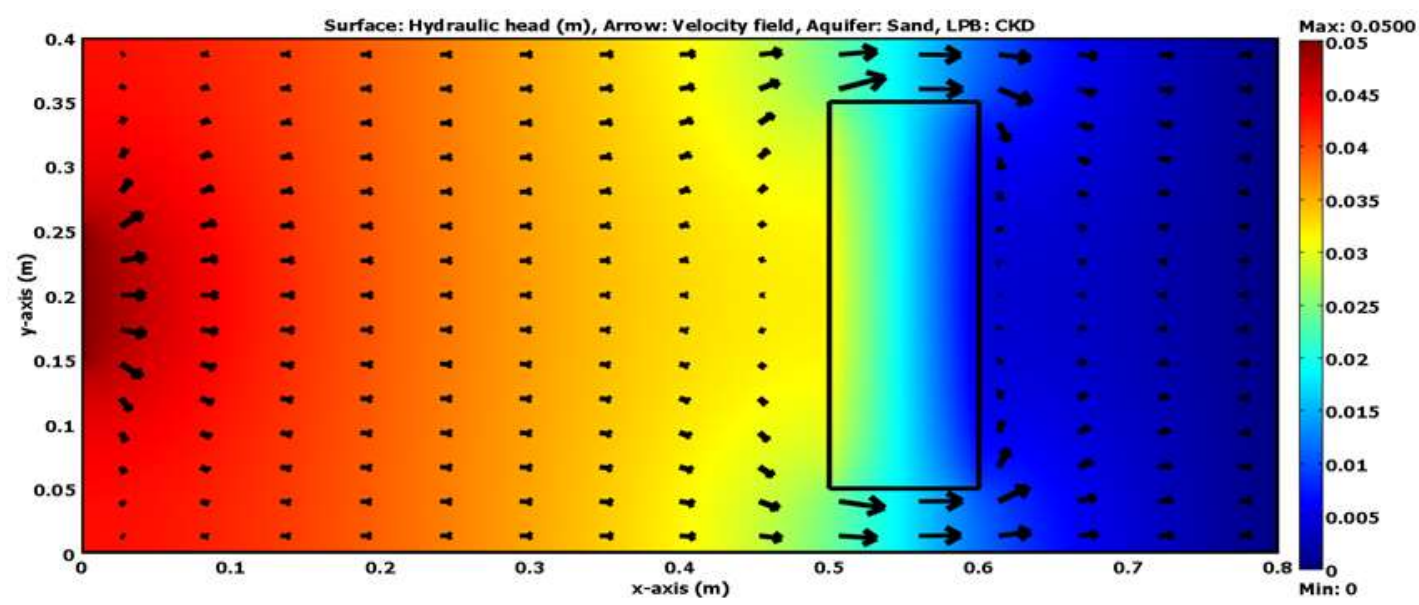

Figure 10. Velocity field and hydraulic head distribution across the bed model as calculated from COMSOL software for steady state

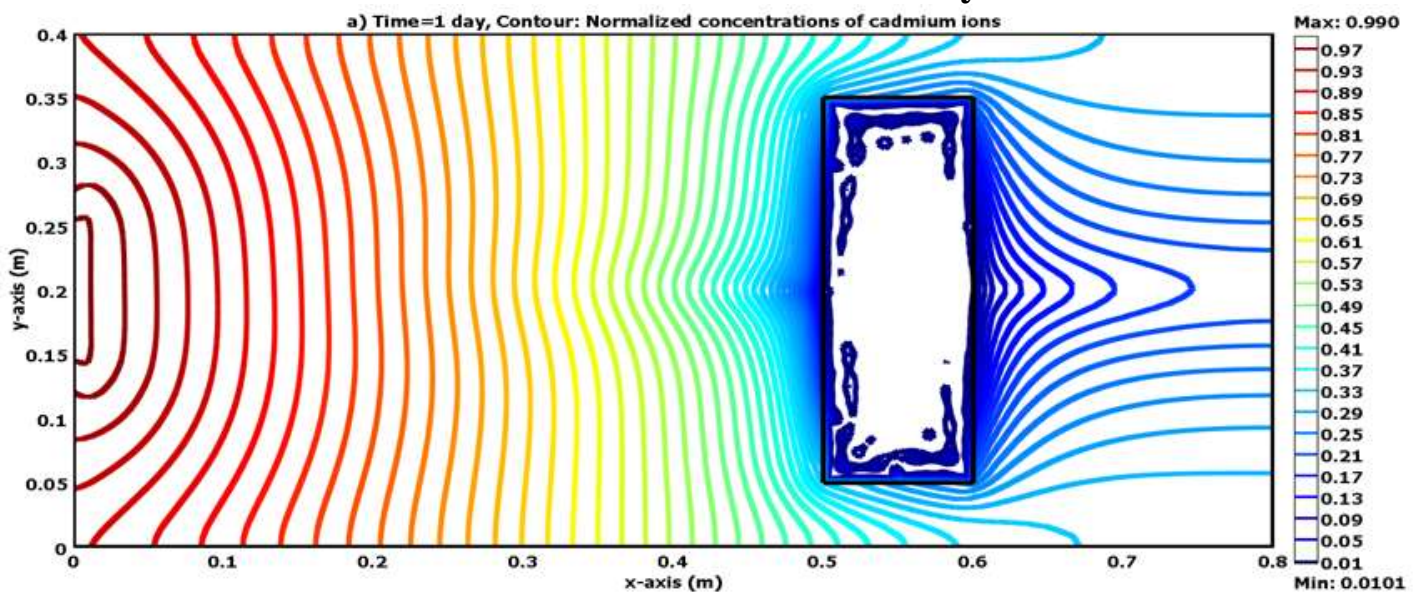

Figure 11. Contours of normalized concentration of cadmium across the 2D bed model as calculated by the COMSOL software for (a) 1, (b) 3 and (c) 7 day

The cement kiln dust resulted from cement industry as byproduct proved have a high ability in the restriction of the Cadmium ions transport present in the aqueous solutions. The best values of the operational conditions for material under consideration are equal to $1 \mathrm{hr}$, $0.7 \mathrm{~g} / 100 \mathrm{~mL}$, and $250 \mathrm{rpm}$ respectively for initial concentration of $50 \mathrm{mg} / \mathrm{L}$ to achieve the maximum removal efficiencies of $97.6 \%$. Results revealed that the average hydraulic conductivity of CKD was equal to $9.7 \times 10^{-15}$ $\mathrm{m} / \mathrm{s}$ and this is satisfied the requirements of LPB.

1- For interaction of Cadmium ions with CKD, Freundlich and Langmuir models are found able to describe the sorption measurements where the values of $\mathrm{R}^{2}$ not less than 0.97 with maximum sorption capacity of $84.1 \mathrm{mg} / \mathrm{g}$; so, the removal process may be governed by the physical and chemical forces.

2- Mathematical model describes in a good manner the flow of water and distribution of the metal ions within the $2 \mathrm{D}$ bed to specify the efficacy of LPB in the protection of the water resources. The outputs of this model as calculated by COMSOL Multiphysics 3.5a are observed in good matching with experimental measurements.

\section{REFRENCES}

1. Abd Ali, Z.T.; L. A. Naji, S.A.A.A.N. Almuktar, A.A.H. Faisal, S.N.Abed, M.Scholz, M.Naushad and T.Ahamad, 2020. Predominant mechanisms for the removal of nickel metal ion from aqueous solution using cement kiln dust. J. Water Process Eng. 33, 101033.

https://doi.org/10.1016/j.jwpe.2019.101033

2. AbdulKareem, H.N and A.I.Alwared, 2019. Immobilization dried mix of algae for copper removal.Iraqi Journal of Agricultural Sciences.50(3):800-808

3. Abichou, T.; C. Benson and T. Edil, 2000. Foundry green sand as a hydraulic barrier: Laboratory study. Journal of Geotechnical and Geoenvironmental Engineering, ASCE, 126 (12) December

4. Adaska, W.S. and D.H. Taubert, 2008. Beneficial uses of cement kiln dust. 
Proceeding of 2008 IEEE/PCA 50th Cement Industry Technical Conf., Miami, FL, IEEEIAS Cement Industry Committee

5. Al-Ghouti M. A.; M. A. M. Khraisheh, S. J. Allen and M. N. Ahmad, 2003. The removal of dyes from textile wastewater: a study of the physical characteristics and adsorption mechanisms of diatomaceous earth. Journal of Environmental Management 69 (30), 229-238

6. Anderson, E. I. and E. Mesa, 2006. The effects of vertical barrier walls on the hydraulic control of contaminated groundwater. Advances in Water Resources 29 7. Volesky, B., 2004. Sorption and Biosorption, BV-Sorbex Inc., Montreal, Canada

8. Bradshaw, S.L.; C.H. Benson and T.L. Rauen, 2016. Hydraulic conductivity of geosynthetic clay liners to recirculated municipal solid waste leachates. Journal of Geotechnical and Geoenvironmental Engineering 142: 04015074

9. Di Natale, F.; M. Di Natale, R. Greco, A.Lancia, C., Laudante and D. Musmarra,2008.Groundwaterprotectin from cadmium contamination by permeable reactive barriers. Journal of Hazardous Materials, 160, 428-434

10. Gheju, M. and A. Miulescu, 2007. Sorption equilibrium of hexavalent chromium on granular activated carbon. Chem. Bull. Politechnica Univ. (Timişoara), 52(66), 1-2, 41-46

11. Hassan, D. F.; A. A. Jafaar and R.J. Mohammed, 2019. Effect of irrigation water salinity and tillage systems on some physical soil properties. Iraqi Journal of Agricultural Sciences. 50(Special Issue):21-24

12. Ho, Y.-S .and G. McKay, 1999. Pseudosecond order model for sorption processes. Process Biochemistry, 34(5), 451-465

13. Krishnani, K.K.; M.X. Xiaoguang, C. Christodoulatos and V.M. Boddu, 2008. Biosorption mechanism of nine different heavy metals onto biomatrix from rice husk, J. Hazard. Mater. 153,1222-1234

14. Khaliefa, Q.M, 2014. Reactive Barrier Treatment Wall Technology for Remediation of Inorganic Contaminated Groundwater. Ph.D. Dissertation, University of Basra
15. Khanna, O. S., 2009. Characterization and Utilization of Cement Kiln Dusts (CKDs) as Partial Replacements of Portland Cement, Ph.D. Dissertation, University of Toronto.

16. Widomski, M.K.; W. Stępniewski and A. Musz-Pomorska, 2018. Clays of different plasticity as materials for landfill liners in rural systems of sustainable waste management, Sustainability 10, 2-16

17. Mason, W.R., 2003. Pollution of groundwater. www.encyclopedia.com > ... > Water: Science and Issues > January 2003

18. Rahi, M. A. and A.A. H. Faisal, 2019. Using horizontal subsurface flow constructed wetland System in the treatment of municipal wastewater for Agriculture purposes. Iraqi Journal of Agricultural Sciences. 50(4):1208.1217

19. Saraya M. E. I. and M. E. Aboul-Fetouh, 2012 Utilization from cement kiln dust in removal of acid dyes. American Journal of Environmental Sciences 8 (1), 16-24

20. Sreekrishnavilasam, A., S. King and M. Santagata, 2006. Characterization of fresh and landfilled cement kiln dust for reuse in construction applications. Engineering Geology, 85(1-2), 165-173

21. Thiruvenkatachari,R. ; S.Vigneswaran and R. Naidu, 2008. Permeable reactive barrier for groundwater remediation. Journal of Industrial and Engineering Chemistry, 14, 145-156

22. Townshend, A. and E. Jackwerth, 1989. Precipitation of major constituents for trace pre-concentration: potential and problems. Pure and App. Chem., 61(9), 1643-1656. Zhu, C., S. Martin, R. Ford and N. Nuhfer, 2003

23. USEPA, 1993b. Report to Congress on Cement Kiln Dust: Methods and Findings. U.S. Environmental Protection Agency, Office of Solid Waste and Emergency Response, EPA-530-R-94-001

24. Worthington, S.R.H. and R.W.N. Soley, 2017. Identifying turbulent flow in carbonate aquifers, J. Hydrol. 552, 70-80.

25. Wang, J. and C. Chen, 2009. Biosorbents for heavy metals removal and their future. Biotechnology Advances, 27, 195-226. 